\title{
FTO Variant, Energy Intake, Physical Activity and Basal Metabolic Rate in Caucasians. The HAPIEE Study
}

\author{
J. A. HUBÁČEK ${ }^{1,2,3}$, H. PIKHART ${ }^{4}$, A. PEASEY ${ }^{4}$, R. KUBÍNOVÁ ${ }^{5}$, M. BOBÁK ${ }^{4}$ \\ ${ }^{1}$ Institute for Clinical and Experimental Medicine, Prague, Czech Republic, ${ }^{2}$ Centre for \\ Cardiovascular Research, Prague, Czech Republic, ${ }^{3}$ South Bohemia University, Faculty for Public \\ Health and Social Studies, Ceske Budejovice, Czech Republic, ${ }^{4}$ Department of Epidemiology and \\ Public Health, University College London, London, United Kingdom, ${ }^{5}$ National Institute of Public \\ Health, Prague, Czech Republic
}

Received August 20, 2010

Accepted September 21, 2010

On-line October 15, 2010

\section{Summary}

The FTO gene variants are the most important genetic determinants of body weight and obesity known so far, but the mechanism of their effect remains unclear. We have analyzed FTO rs17817449 variant (G>T in first intron) in 6024 adults aged 45-69 years to assess the potential mediating role of diet and physical activity. Diet was assessed by a 140 -item food frequency questionnaire. Physical activity was measured by hours spent during a typical week by sport, walking and other activities outside of work requiring heavy and medium physical activity. Basal metabolic rate was calculated according Schofield formula. The FTO variant was significantly associated with body mass index (means in GG, GT and TT carriers were 28.7, 28.2 and 27.8 $\mathrm{kg} / \mathrm{m}^{2}, \mathrm{p}<0.001$ ) and basal metabolic rate (BMR) (means in GG, GT and TT were 1603, 1588 and 1576 kcal per day, respectively, $\mathrm{p}<0.008$ ) but it was not associated with physical activity, total energy intake or with energy intakes from fat, carbohydrates, proteins or alcohol. Results were essentially similar in men and women and the adjustment for physical activity or dietary energy intake did not reduce the effect of the FTO polymorphism. Means of BMR per kg of body weight was lowest in GG carriers (20.09, 20.21 for $G T$ and 20.30 for $\Pi, p<0.006$ ) and this effect was more pronounced in females. These results suggest that the effect of the FTO rs17817449 variant on BMI in Caucasian adults is not mediated by energy intake or physical activity, but some effect on BMR per $\mathrm{kg}$ of body weight is possible.

\section{Key words}

FTO • Polymorphism • Body mass index • Energy expenditure • Physical activity $\bullet$ Basal metabolic rate

\section{Corresponding author}

Jaroslav A. Hubacek, IKEM-DEM-LMG, Videnska 1958/9, 14021 Prague 4, Czech Republic. Fax: +420 241721 666. E-mail: jahb@ikem.cz

\section{Introduction}

Obesity is one of the major global health problems. The prevalence of obesity increased dramatically over the last decades, and it is estimated that currently only one third of the population in the most affected countries has a normal $\left(18-25 \mathrm{~kg} / \mathrm{m}^{2}\right)$ body mass index (BMI).

Generally, obesity results from the interactions between unhealthy life style (abundant energy intake and low physical activity) and genetic predispositions, although some other factors such as non-exercise activity thermogenesis, sleeping behavior, higher inside temperature comfort, or different environmental chemicals and psychosocial factors play also an important role (Hubacek 2009, Adámková et al. 2009).

It has been estimated that genetic factors explain about $40-60 \%$ of the variation in obesity (Wardle et al. 2008, Hainer et al. 2008). Recently, many new genes associated with obesity have been identified using genome wide association studies (for example see Thorleifsson et al. 2009). Among the newly detected genes, particular interest is focused on the FTO gene, the first locus unequivocally associated with BMI values. FTO ("fat mass and obesity related", gene ID 79068, 
OMIM accession number 610966) gene (and its SNPs) was detected by several research groups as a significant predictor of body mass index (Dina et al. 2007, Frayling et al. 2007, Tönjes et al. 2010). The FTO gene variants are associated with BMI in a wide range of populations, and the effect is not restricted to Caucasians (Dina et al. 2007, Frayling et al. 2007, Hunt et al. 2008, Hubacek et al. 2008, Hubacek et al. 2009); it affects BMI also in Asian (Ohashi et al. 2007, Tan et al. 2008) and African populations (Hennig et al. 2009, Liu et al. 2010).

FTO is widely expressed in almost all tissue, but the exact role of the FTO is unknown. The FTO exhibits slight DNA demethylase (Gerken et al. 2007) and nonheme dioxygenase activities (Sanchez-Pulido and Andrade-Navarro, 2007), but no direct function in energy homeostasis has been described. It has been shown that Fto knock-out mice develop postnatal growth retardation with a significant reduction of adipose tissue. The extreme leanness of Fto knock-out mice was a consequence of increased energy expenditure (despite the decreased activity of the animals and increased energy intake (Fischer et al. 2009). In humans, reports on the potential impacts of FTO variants on dietary intake and/or energy expenditure have been inconsistent; this inconsistency has in some cases been caused by a insufficient number of analyzed individuals and low statistical power of the studies (Speakman et al. 2008, Cecil et al. 2008, Berentzen et al. 2008, Timpson et al. 2008, Johnson et al. 2009, Hakanen et al. 2009, Haupt et al. 2009, Liu et al. 2010, Hasselbalch et al. 2010).

We have examined the hypothesis that BMI associated FTO variant is related to elevated energy intake, lower physical activity performed or with basal metabolic rate in a large population sample of middleaged adults.

\section{Material and Methods}

\section{Subjects}

The study subjects come from the Czech part of the HAPIEE (Health, Alcohol and Psychosocial factors In Eastern Europe) project which examined random population samples of men and women aged 45-69 years in seven Czech towns: Jihlava, Havirov, Hradec Kralove, Karvina, Kromeriz, Liberec and Usti nad Labem. Details of the study have been described elsewhere (Peasey et al. 2006). Briefly, 8856 individuals have been recruited (response rate 55\%), 6681 (3079 males and 3602 females) of which provided a blood sample and have
DNA material available. Participants completed an extensive questionnaire on their medical history, health status, life style, diet and socioeconomic and psychosocial factors, underwent a short examination, including anthropometry, and provided a blood sample. After validation of the dietary intake information (Boylan et al. 2009), 6024 individuals with complete data on all required variables were statistically analyzed in details. The study was approved by the local ethics committees at both Czech National Institute of Public health and University College London.

\section{Genetic analysis}

DNA was extracted using salting out method (Miller et al. 1988), and FTO SNP rs17817449 was genotyped using PCR - RFLP as described elsewhere (Hubacek et al. 2008). To ensure accuracy of genotyping, one plate (containing 94 DNA samples) was analyzed twice within one week with $100 \%$ conformity. Call rate for genotyping was $96 \%$.

\section{Dietary intake and BMR}

Dietary intake was assessed by a 140-item food frequency questionnaire (FFQ) (Willett et al. 1985, Brunner et al. 2001). The intake of total energy, fats, carbohydrates, proteins and alcohol is estimated from the FFQ, using the McCance and Widdowson's The Composition of Foods (Food Standards Agency, 2002) and correcting for major differences in composition of principal foods and local foods and recipes (Boylan et al. 2009). Basal metabolic rate was calculated according Schofield (1985).

\section{Physical activity}

Physical activity has been assessed using questions on the number of hours spent by participants during a typical week in sports, walking and other activities outside of work requiring heavy or medium physical activity ( 2 questions). The potential confounding effect of physical disability was taken into account using the physical functioning module of the SF-36 questionnaire (Wagner et al. 1998).

\section{Statistical analyses}

Deviation of genotypes distributions from Hardy-Weinberg equilibrium were analyzed using the chi-square test (http://www.tufts.edu/ mcourt01/ Documents/Court\%201ab\%20-\%20HW\%20calculator .xls). One-way analysis of variance in STATA statistical 
Table 1. Baseline characteristics for analyzed individuals $(\mathrm{N}=6024)$.

\begin{tabular}{lccc}
\hline & All subjects & Males & Females \\
\hline$N$ & 6024 & 2780 & 3244 \\
Age $($ years) & $58.1 \pm 6.9$ & $58.5 \pm 6.9$ & $57.7 \pm 6.9$ \\
BMI $\left(\mathrm{kg} / \mathrm{m}^{2}\right)$ & $28.2 \pm 4.6$ & $28.2 \pm 3.9$ & $28.1 \pm 5.1$ \\
WHR & $0.885 \pm 0.085$ & $0.944 \pm 0.059$ & $0.834 \pm 0.069$ \\
Diabetes & $657(10.9 \%)$ & $359(12.9 \%)$ & $298(9.2 \%)$ \\
Current smoking & $1531(25.7 \%)$ & $793(28.8 \%)$ & $738(23.0 \%)$ \\
Total energy intake & $2038 \pm 710$ & $2103 \pm 705$ & $1982 \pm 709$ \\
Total fat energy intake & $742 \pm 299$ & $772 \pm 308$ & $717 \pm 289$ \\
Total carbohydrate energy intake & $886 \pm 353$ & $868 \pm 330$ & $901 \pm 372$ \\
Total protein energy intake & $354 \pm 130$ & $369 \pm 134$ & $342 \pm 126$ \\
Total energy intake in alcohol & $60 \pm 99$ & $101 \pm 125$ & $26 \pm 49$ \\
Physical activity (h/week)* & $4.4 \pm 5.3$ & $4.4 \pm 5.4$ & $4.4 \pm 5.2$ \\
Basal metabolic rate & $1587 \pm 237$ & $1794 \pm 164$ & $1412 \pm 118$ \\
BMR/kg of body weight & $20.21 \pm 2.18$ & $21.01 \pm 1.85$ & $19.54 \pm 2.21$ \\
\hline
\end{tabular}

* h/week in sports/games/walking/hiking. Data are given like numbers / percents or mean \pm SD. Energy intakes are in $\mathrm{kcal} / \mathrm{day}$.

software (version 9; College Station, TX) was used for statistical analyses comparing dietary intake, BMR and physical activity between individuals with different genotypes. Mean $\pm \mathrm{SD}$ are reported for each exposure and genotype group, and P-values less than 0.05 were considered to be significant.

\section{Results}

Study subjects

The basic characteristics of the groups under study are summarized in Table 1. The distribution of individual genotypes is within Hardy-Weinberg equilibrium $(\mathrm{P}=0.07)$ and is similar to the neighboring European samples reported previously (Dina et al. 2007, Frayling et al. 2007).

The total energy intake per day was higher in males than in females $(2103 \pm 705 \mathrm{kcal}$ vs $1982 \pm 709 \mathrm{kcal})$ and this difference was caused generally by higher fat and ethanol intake in males (Table 1), while physical activity was similar in males and females. As expected, basal metabolic rate and basal metabolic rate per $\mathrm{kg}$ of body weight were also higher in males.

Consistently with the results described in original articles (Dina et al. 2007, Frayling et al. 2007, for reviewed see Fawcett and Barroso 2010) rs17817449 $\mathrm{G}$ allele was significantly associated with obesity related phenotype (BMI) in a total combined sample $(\mathrm{P}=0.0001)$ as we have described before (Hubacek et al. 2008) and the presence of the $\mathrm{G}$ allele increase the BMI in linear trend both in males $(\mathrm{P}<0.005)$ and females $(\mathrm{P}<0.001)$. There were no significant associations of the FTO gene SNP with waist-hip ratio.

Association between FTO SNP and energy intake, physical activity and basal metabolic rate

Associations between FTO genotype and variables of interest are summarized in Table 2. FTO SNP rs17817449 was not associated with the mean values of the total energy intake. Similarly, total fat, carbohydrates, protein and alcohol energy intakes are independent on FTO genotypes in entire population or in males or females.

Basal metabolic rate was higher in GG homozygotes $(\mathrm{P}=0.008)$ and the effect was more pronounced in females $(\mathrm{P}=0.02)$ than in males $(\mathrm{P}=0.08)$. Interestingly, the basal metabolic rate per kilogram of body height was highest in carriers of the TT genotype, but this trends was observed only in females $(\mathrm{P}=0.006)$, not in males $(\mathrm{P}=0.42)$.

Mediating effect of physical activity, dietary intake and basal metabolic rate

Finally, we have examined whether the effect of the FTO genotype on BMI is statistically explained (attenuated) by energy intake, physical activity and basal metabolic rate. We did so by adjusting the effects of the FTO genotype on BMI for the potential mediators. 
Table 2. Association between FTO rs17817449 variant, energy intake, physical activity and basal metabolic rate in HAPIEE Slavic Czech population.

\begin{tabular}{|c|c|c|c|c|}
\hline & \multicolumn{3}{|c|}{ FTO } & \multirow{3}{*}{ P-value } \\
\hline & GG & GT & TT & \\
\hline$N$ & 1,157 & 2,886 & 1,981 & \\
\hline \multicolumn{5}{|l|}{ ENTIRE POPULATION } \\
\hline Total energy intake & $2050 \pm 712$ & $2031 \pm 702$ & $2040 \pm 721$ & 0.75 \\
\hline Total fat energy intake & $753 \pm 300$ & $739 \pm 298$ & $740 \pm 301$ & 0.38 \\
\hline Total carbohydrate energy intake & $886 \pm 352$ & $881 \pm 347$ & $892 \pm 363$ & 0.59 \\
\hline Total protein energy intake & $357 \pm 13$ & $355 \pm 130$ & $352 \pm 131$ & 0.61 \\
\hline Total energy intake in alcohol & $59 \pm 101$ & $61 \pm 101$ & $60 \pm 96$ & 0.82 \\
\hline Physical activity* & $4.3 \pm 5.1$ & $4.4 \pm 5.3$ & $4.4 \pm 5.4$ & 0.94 \\
\hline Basal metabolic rate (BMR) & $1603 \pm 243$ & $1588 \pm 235$ & $1576 \pm 236$ & 0.008 \\
\hline$B M R / k g$ of body weight & $20.09 \pm 2.20$ & $20.21 \pm 2.16$ & $20.30 \pm 2.18$ & 0.03 \\
\hline \multicolumn{5}{|l|}{$M A L E S$} \\
\hline Total energy intake & $2078 \pm 697$ & $2104 \pm 698$ & $2117 \pm 722$ & 0.60 \\
\hline Total fat energy intake & $771 \pm 303$ & $774 \pm 312$ & $769 \pm 305$ & 0.94 \\
\hline Total carbohydrate energy intake & $855 \pm 314$ & $865 \pm 322$ & $880 \pm 352$ & 0.34 \\
\hline Total protein energy intake & $363 \pm 131$ & $370 \pm 135$ & $371 \pm 136$ & 0.49 \\
\hline Total energy intake in alcohol & $98 \pm 128$ & $101 \pm 126$ & $103 \pm 121$ & 0.73 \\
\hline Physical activity* & $4.3 \pm 5.2$ & $4.4 \pm 5.5$ & $4.3 \pm 5.4$ & 0.79 \\
\hline Basal metabolic rate & $1808 \pm 169$ & $1792 \pm 161$ & $1788 \pm 163$ & 0.08 \\
\hline$B M R / k g$ of body weight & $20.92 \pm 1.91$ & $21.01 \pm 1.84$ & $21.06 \pm 1.83$ & 0.42 \\
\hline \multicolumn{5}{|l|}{ FEMALES } \\
\hline Total energy intake & $2024 \pm 724$ & $1968 \pm 700$ & $1977 \pm 714$ & 0.25 \\
\hline Total fat energy intake & $738 \pm 297$ & $709 \pm 281$ & $716 \pm 296$ & 0.12 \\
\hline Total carbohydrate energy intake & $914 \pm 381$ & $895 \pm 368$ & $901 \pm 371$ & 0.56 \\
\hline Total protein energy intake & $352 \pm 129$ & $341 \pm 125$ & $337 \pm 125$ & 0.07 \\
\hline Total energy intake in alcohol & $24 \pm 44$ & $26 \pm 51$ & $26 \pm 48$ & 0.54 \\
\hline Physical activity* & $4.4 \pm 5.0$ & $4.4 \pm 5.2$ & $4.4 \pm 5.4$ & 0.99 \\
\hline Basal metabolic rate & $1419 \pm 121$ & $1414 \pm 120$ & $1404 \pm 113$ & 0.02 \\
\hline$B M R / k g$ of body weight & $19.33 \pm 2.17$ & $19.52 \pm 2.19$ & $19.69 \pm 2.25$ & 0.006 \\
\hline
\end{tabular}

* h/week in sports/games/walking/hiking. Data are given like numbers / percents or mean \pm SD. Energy intakes are in kcal/day.

The results are shown in Table 3. Adjustment for physical activity and energy intake did not attenuate the effect of the FTO genotype (neither did adjustments for energy from specific macro-nutrients, not shown in table).

\section{Discussion}

This large population-based study provides robust evidence that dietary intake of energy and physical activity are not associated with the FTO genotype, and they do not mediate the FTO gene effect on body mass index in Caucasian adults. We also found an association between the FTO gene variant and basal metabolic rate per kilogram of body weight, and basal metabolic rate also statistically "explained" part of the association between the FTO genotype and body mass index.

The major limitation of our data related to the self-reported dietary intake. Despite continuous quality control, self reported dietary intake assessment is likely to be inaccurate. Firstly, most people underestimate there 
Table 3. Association between the FTO genotype and BMI after adjustment for physical activity, total energy intake and basal metabolic rate; the figures are linear regression coefficient ( $95 \%$ confidence interval) for the differences between carriers of $\Pi$ and GT genotypes, compared with GG (reference).*

FTO
GG
GT
TT
P-value

\begin{tabular}{lcccc}
\hline ENTIRE POPULATION & & & & \\
\hline Crude effect & 0.0 & $-0.42(-0.72,-0.11)$ & $-0.84(-1.17,-0.51)$ & $<0.001$ \\
Adj. for energy intake & 0.0 & $-0.42(-0.72,-0.11)$ & $-0.84(-1.17,-0.51)$ & $<0.001$ \\
Adj. for physical activity & 0.0 & $-0.42(-0.73,-0.11)$ & $-0.84(-1.16,-0.51)$ & $<0.001$ \\
Adj. for BMR & 0.0 & $-0.12(-0.30,0.06)$ & $-0.37(-0.56,-0.17)$ & $<0.001$ \\
Adj. for BMR/kg & 0.0 & $-0.18(-0.35,-0.01)$ & $-0.28(-0.46,-0.10)$ & 0.01 \\
\hline MALES & & & & \\
\hline Crude effect* & 0.0 & $-0.31(-0.70,0.08)$ & $-0.64(-1.06,-0.22)$ & 0.01 \\
Adj. for energy intake & 0.0 & $-0.31(-0.70,0.08)$ & $-0.64(-1.05,-0.22)$ & 0.01 \\
Adj. for physical activity & 0.0 & $-0.29(-0.68,0.10)$ & $-0.60(-1.01,-0.18)$ & 0.02 \\
Adj. for BMR & 0.0 & $-0.10(-0.33,0.13)$ & $-0.34(-0.59,-0.09)$ & 0.01 \\
Adj. for BMR/kg & 0.0 & $-0.20(-0.44,0.03)$ & $-0.34(-0.60,-0.09)$ & 0.03 \\
\hline FEMALES & & & & \\
\hline Crude effect* & & & & \\
Adj. for energy intake & 0.0 & $-0.48(-0.95,-0.02)$ & $-0.99(-1.48,-0.50)$ & $<0.001$ \\
Adj. for physical activity & 0.0 & $-0.50(-0.96,-0.03)$ & $-1.00(-1.49,-0.51)$ & $<0.001$ \\
Adj. for BMR & 0.0 & $-0.51(-0.98,-0.04)$ & $-1.03(-1.52,-0.53)$ & $<0.001$ \\
Adj. for BMR/kg & 0.0 & $-0.16(-0.39,0.07)$ & $-0.33(-0.57,-0.08)$ & 0.03 \\
\hline
\end{tabular}

* all models adjusted for age

dietary intakes (Schoeller 1995). And secondly, there is a considerable random error in reporting diet. Although underestimation is likely to be similar between carriers of different FTO genotypes, obese individuals are more prone to such underestimation (Westerterp and Goris 2002) and this may obscure differences in dietary intakes between individuals with different FTO genotypes. Random misclassification would further dilute any association. Similar argument may apply to physical activity. Although the large size of the study would, to some extent, counterbalance the influence of misclassification, it is nevertheless possible that the lack of association between FTO and energy intake and physical activity is due to imprecise measurement of diet and physical activity.

Our results are in contrast with the study performed by Speakman and colleagues (2008) who did not find a significant association between FTO and basal metabolic rate, however, they include 150 individuals only and the study is clearly underpowered to detect the effect which is according to our study, expected to be just about $20-25 \mathrm{kcal} / \mathrm{kg} /$ day between homozygotes.

The FTO gene variants were originally described to be associated with BMI values in Caucasians. The gene for the FTO codes for the protein with enzymatic activities that do not seem to have a direct effect on energy management; moreover, described enzymatic activities are detectable but low. In general, there are two easy possibilities suggested how the FTO gene can influence body weight: either through energy intake or through energy expenditure.

However, the possible associations of the FTO gene variants with the preference of energy dense food, higher fat intake or markers of physical activity in previous studies are inconsistent, and the exact mechanism of the effect of FTO on higher BMI/obesity development remains elusive.

The lack of the association between energy intake and physical activity performed in our study is in agreement with the previous findings of Hakanen et al. 
(2009) who did not find an association between energy intake and physical activity at age 15 , with data from Liu et al. (2010) who failed to detect an association between energy intake and physical activity in almost two thousands adults, and with a large study of 756 twin pairs which also failed to associate $F T O$ variant with energy intake or physical activity (Hasselbalch et al. 2010). Dietary energy intake was also not associated with FTO variant in a group of about 2300 prepubertal children (Johnson et al. 2009). Finally, Berentzen et al. (2008) did not detect an association between energy expenditure or energy intake and FTO genotypes.

However, there have also been positive reports. The obesity associated allele was associated with increased energy intake (but not with the weight of food ingested) in a small sample of 97 children (Cecil et al. 2008), in 150 Germans who underwent an lifestyle intervention program (Haupt et al. 2009); finally, Timpson et al. (2008) have observed a significant effect of FTO variant on the both total energy and fat daily energy intake on much larger group of 3500 children. The FTO genotype was also found to be associated with lower satiety responsiveness and elevated enjoyment of food in children (Wardle et al. 2008).

Overall, the literature does not provide a strong support for an effect of the FTO alleles on physical activity and that the effect on dietary energy intake, if any, was detected only in pre-pubertal and pubertal children but not in adults. Not in all studies were analyzed identical SNPs but it is unlikely that this fact can explain the obtained discrepancies - all variants have been associated with mean BMI in a similar fashion and all SNPs within the FTO first intron locus are in almost complete linkage disequilibrium.

In our study, carriers of the GG genotype (rs 17817449), which is associated with elevated BMI, had slightly lower basal metabolic rate per kilogram of body weight. Previous studies, to our knowledge, did not report such association. A small effect on resting metabolic rate was suggested in the Quebeck Family study (Do et al. 2008), but it was in the opposite direction than in our study (i.e. higher RMR was observed in the obesityassociated genotype) and it disappeared after adjustment for fat composition. Haupt et al. (2009) also did not observe an association between FTO and basal metabolic rate. However, both studies mentioned above were very small, with 50 and 150 participants, respectively. Our observation may be a numerical artifact - basal metabolic rate was calculated from age, sex, height and weight (rather than measured directly); it is therefore possible that its strong association with body mass index, and its mediating effect on the FTO-body mass index relationship, is just due to the fact that it has been estimated from the same variables as body mass index. Our finding needs to be confirmed by other studies, preferably using directly measured basal metabolic rate.

In the light of the literature, and our study, the exact mechanisms of the FTO effect on body weight remain unknown. There is another potential mechanism how the FTO could affect body weight, namely increased lipolysis (Wåhlén et al. 2008) but empirical evidence on this hypothesis is not available. At present, the possibility should be considered that the variants within the first introns of FTO are in strong linkage disequilibrium not just with each other but also with variants in neighboring genes - for example, the gene for retinitis pigmentosa GTPase regulator-interacting protein like 1 was suggested (Fawcet and Barroso 2010), although the association of this gene with energy metabolism remains speculative.

In conclusion, our study confirms previous findings that the FTO genotype is not associated with energy intake (and extend this finding also on total fat, carbohydrates, protein and alcohol energy intakes) or physically activity. We have detected that it may have an effect on basal metabolic rate per kilogram of body weight but the issue of a numerical artifact needs to be clarified, and further studies should investigate whether the effect of FTO variants on basal metabolic rate per kilogram of body weight is a plausible explanation for the FTO effect on body weight.

\section{Conflict of Interest}

There is no conflict of interest.

\section{Acknowledgements}

This project was supported by grants from IKEM, CR, (project No. 00023001), by MEYS, CR (project No. 1M0510), by the Wellcome Trust, UK and by the US National Institute Aging.
Abbreviations
BMI, body mass index; $\mathrm{CR}$, call rate; FTO, fat mass and obesity related; MAF, minor allele frequency; SNP, single nucleotide polymorphisms; WHR, waist hip ratio 


\section{References}

ADÁMKOVÁ V, HUBÁCEK JA, LÁNSKÁ V, VRABLÍK M, KRÁLOVÁ LESNÁ I, SUCHÁNEK P, ZIMMELOVÁ P, VELEMINSKÝ M: Association between duration of the sleep and body weight. Physiol Res 58 (Suppl 1): S27-S31, 2009.

BERENTZEN T, KRING SI, HOLST C, ZIMMERMANN E, JESS T, HANSEN T, PEDERSEN O, TOUBRO S, ASTRUP A, SØRENSEN TI: Lack of association of fatness-related FTO gene variants with energy expenditure or physical activity. J Clin Endocrinol Metab 93: 2904-2908, 2008.

BOYLAN S, WELCH A, PIKHART H, MALYUTINA S, PAJAK A, KUBINOVA R, BRAGINA O, SIMONOVA G, STEPANIAK U, GILIS-JANUSZEWSKA A, MILLA L, PEASEY A, MARMOT M, BOBAK M: Dietary habits in three Central and Eastern European countries: the HAPIEE study. BMC Public Health 9: 439, 2009.

BRUNNER E, STALLONE D, JUNEJA M, BINGHAM S, MARMOT M: Dietary assessment in Whitehall II: comparison of $7 \mathrm{~d}$ diet diary and food-frequency questionnaire and validity against biomarkers. $\mathrm{Br} J \mathrm{Nutr} \mathbf{8 6}$ : 405-414, 2001.

CECIL JE, TAVENDALE R, WATT P, HETHERINGTON MM, PALMER CN: An obesity-associated FTO gene variant and increased energy intake in children. N Engl J Med 359: 2558-2566, 2008.

DINA C, MEYRE D, GALLINA S, DURAND E, KÖRNER A, JACOBSON P, CARLSSON LM, KIESS W, VATIN V, LECOEUR C, DELPLANQUE J, VAILLANT E, PATTOU F, RUIZ J, WEILL J, LEVYMARCHAL C, HORBER F, POTOCZNA N, HERCBERG S, LE STUNFF C, BOUGNÈRES P, KOVACS P, MARRE M, BALKAU B, CAUCHI S, CHÈVRE JC, FROGUEL P: Variation in FTO contributes to childhood obesity and severe adult obesity. Nat Genet 39: 724-726, 2007. Corrigendum in: Nat Genet 39: 1285, 2007.

DO R, BAILEY SD, DESBIENS K, BELISLE A, MONTPETIT A, BOUCHARD C, PÉRUSSE L, VOHL MC, ENGERT JC: Genetic variants of FTO influence adiposity, insulin sensitivity, leptin levels, and resting metabolic rate in the Quebec Family Study. Diabetes 57:1147-1150, 2008.

FAWCETT KA, BARROSO I: The genetics of obesity: FTO leads the way. Trends Genet 26: 266-274, 2010.

FISCHER J, KOCH L, EMMERLING C, VIERKOTTEN J, PETERS T, BRÜNING JC, RÜTHER U: Inactivation of the Fto gene protects from obesity. Nature 458: 894-898, 2009.

Food Standards Agency. McCance and Widdowson's The Composition of Foods. Sixth Summary Edition. Cambridge: Royal Society of Chemistry, 2002.

FRAYLING TM, TIMPSON NJ, WEEDON MN, ZEGGINI E, FREATHY RM, LINDGREN CM, PERRY JR, ELLIOTT KS, LANGO H, RAYNER NW, SHIELDS B, HARRIES LW, BARRETT JC, ELLARD S, GROVES CJ, KNIGHT B, PATCH AM, NESS AR, EBRAHIM S, LAWLOR DA, RING SM, BENSHLOMO Y, JARVELIN MR, SOVIO U, BENNETT AJ, MELZER D, FERRUCCI L, LOOS RJ, BARROSO I, WAREHAM NJ, KARPE F, OWEN KR, CARDON LR, WALKER M, HITMAN GA, PALMER CN, DONEY AS, MORRIS AD, SMITH GD, HATTERSLEY AT, MCCARTHY MI: A common variant in the FTO gene is associated with body mass index and predisposes to childhood and adult obesity. Science 316: 889-894, 2007.

GERKEN T, GIRARD CA, TUNG YC, WEBBY CJ, SAUDEK V, HEWITSON KS, YEO GS, MCDONOUGH MA, CUNLIFFE S, MCNEILL LA, GALVANOVSKIS J, RORSMAN P, ROBINS P, PRIEUR X, COLL AP, MA M, JOVANOVIC Z, FAROOQI IS, SEDGWICK B, BARROSO I, LINDAHL T, PONTING CP, ASHCROFT, O'RAHILLY S, SCHOFIELD CJ: The obesity-associated FTO gene encodes a 2-oxoglutaratedependent nucleic acid demethylase. Science 318: 1469-1472, 2007.

HAINER V, ZAMRAZILOVÁ H, SPÁLOVÁ J, HAINEROVÁ I, KUNESOVÁ M, ALDHOON B, BENDLOVÁ B: Role of hereditary factors in weight loss and its maintenance. Physiol Res 57 (Suppl 1): S1-S15, 2008.

HAKANEN M, RAITAKARI OT, LEHTIMÄKI T, PELTONEN N, PAHKALA K, SILLANMÄKI L, LAGSTRÖM H, VIIKARI J, SIMELL O, RÖNNEMAA T: FTO genotype is associated with body mass index after the age of seven years but not with energy intake or leisure-time physical activity. $J$ Clin Endocrinol Metab 94: 1281-1287, 2009. 
HASSELBALCH AL, ANGQUIST L, CHRISTIANSEN L, HEITMANN BL, KYVIK KO, SØRENSEN TI: A variant in the fat mass and obesity-associated gene (FTO) and variants near the melanocortin-4 receptor gene (MC4R) do not influence dietary intake. J Nutr 140: 831-834, 2010.

HAUPT A, THAMER C, STAIGER H, TSCHRITTER O, KIRCHHOFF K, MACHICAO F, HÄRING HU, STEFAN N, FRITSCHE A: Variation in the FTO gene influences food intake but not energy expenditure. Exp Clin Endocrinol Diabetes 117: 194-197, 2009.

HENNIG BJ, FULFORD AJ, SIRUGO G, RAYCO-SOLON P, HATTERSLEY AT, FRAYLING TM, PRENTICE AM: FTO gene variation and measures of body mass in an African population. BMC Med Genet 10: 21, 2009.

HUBACEK JA, BOHUSLAVOVA R, KUTHANOVA L, KUBINOVA R, PEASEY A, PIKHART H, MARMOT MG, BOBAK M: The FTO gene and obesity in a large Eastern European population sample: the HAPIEE study. Obesity (Silver Spring) 16: 2764-2766, 2008.

HUBACEK JA: Eat less and exercise more - is it really enough to knock down the obesity pandemia? Physiol Res $\mathbf{5 8}$ (Suppl 1): S1-S6, 2009.

HUBACEK JA, PITHA J, ADAMKOVA V, LANSKA V, POLEDNE R: A common variant in the FTO gene is associated with body mass index in males and postmenopausal females but not in premenopausal females. Czech post-MONICA and 3PMFs studies. Clin Chem Lab Med 47: 387-390, 2009.

HUNT SC, STONE S, XIN Y, SCHERER CA, MAGNESS CL, IADONATO SP, HOPKINS PN, ADAMS TD: Association of the FTO gene with BMI. Obesity (Silver Spring) 16: 902-904, 2008.

JOHNSON L, VAN JAARSVELD CH, EMMETT PM, ROGERS IS, NESS AR, HATTERSLEY AT, TIMPSON NJ, SMITH GD, JEBB SA: Dietary energy density affects fat mass in early adolescence and is not modified by FTO variants. PLoS One 4: e4594, 2009.

LIU G, ZHU H, LAGOU V, GUTIN B, STALLMANN-JORGENSEN IS, TREIBER FA, DONG Y, SNIEDER H: FTO variant rs9939609 is associated with body mass index and waist circumference, but not with energy intake or physical activity in European- and African- American youth. BMC Med Genet 11: 57, 2010.

MILLER SA, DYKES DD, POLESKY HF: A simple salting out procedure for DNA extraction from human nucleated cells. Nucleic Acid Res 16: 1215, 1988.

OHASHI J, NAKA I, KIMURA R, NATSUHARA K, YAMAUCHI T, FURUSAWA T, NAKAZAWA M, ATAKA Y, PATARAPOTIKUL J, NUCHNOI P, TOKUNAGA K, ISHIDA T, INAOKA T, MATSUMURA Y, OHTSUKA R: FTO polymorphism in oceanic populations. J Hum Genet 52: 1031-1035, 2007.

PEASEY A, BOBAK M, KUBINOVA R, MALYUTINA S, PAJAK A, TAMOSIUNAS A, PIKHART H, NICHOLSON A, MARMOT M: Determinants of cardiovascular disease and other non-communicable diseases in Central and Eastern Europe: rationale and design of the HAPIEE study. BMC Public Health 6: 255, 2006.

SANCHEZ-PULIDO L, ANDRADE-NAVARRO MA: The FTO (fat mas and obesity associated) gene codes for a novel member of the non-heme dioxygenase superfamily. BMC Biochem 8: 23, 2007.

SCHOELLER DA: Limitations in the assessment of dietary intake by self-report. Metabolism 44 (Suppl 2): 18-22, 1995.

SCHOFIELD WN: Predicting basal metabolic rate, new standards and review of previous work. Hum Nutr Clin Nutr 39: 5-41, 1985.

SPEAKMAN JR, RANCE KA, JOHNSTONE AM: Polymorphisms of the FTO gene are associated with variation in energy intake, but not energy expenditure. Obesity (Silver Spring) 16: 1961-1965, 2008.

TAN JT, DORAJOO R, SEIELSTAD M, SIM XL, ONG RT, CHIA KS, WONG TY, SAW SM, CHEW SK, AUNG T, TAI ES: FTO variants are associated with obesity in the Chinese and Malay populations in Singapore. Diabetes 57: 2851-2857, 2008.

THORLEIFSSON G, WALTERS GB, GUDBJARTSSON DF, STEINTHORSDOTTIR V, SULEM P, HELGADOTTIR A, STYRKARSDOTTIR U, GRETARSDOTTIR S, THORLACIUS S, JONSDOTTIR I, JONSDOTTIR T, OLAFSDOTTIR EJ, OLAFSDOTTIR GH, JONSSON T, JONSSON F, BORCH-JOHNSEN K, HANSEN T, ANDERSEN G, JORGENSEN T, LAURITZEN T, ABEN KK, VERBEEK AL, ROELEVELD N, KAMPMAN E, YANEK LR, BECKER LC, TRYGGVADOTTIR L, RAFNAR T, BECKER DM, GULCHER J, KIEMENEY LA, PEDERSEN O, KONG A, THORSTEINSDOTTIR U, STEFANSSON K: Genome-wide association yields new sequence variants at seven loci that associate with measures of obesity. Nat Genet 41: 18-24, 2009. 
TIMPSON NJ, EMMETT PM, FRAYLING TM, ROGERS I, HATTERSLEY AT, MCCARTHY MI, DAVEY SMITH G: The fat mass- and obesity-associated locus and dietary intake in children. Am J Clin Nutr 88: 971-978, 2008.

TÖNJES A, ZEGGINI E, KOVACS P, BÖTTCHER Y, SCHLEINITZ D, DIETRICH K, MORRIS AP, ENIGK B, RAYNER NW, KORIATH M, ESZLINGER M, KEMPPINEN A, PROKOPENKO I, HOFFMANN K, TEUPSER D, THIERY J, KROHN K, MCCARTHY MI, STUMVOLL M: Association of FTO variants with BMI and fat mass in the self-contained population of Sorbs in Germany. Eur J Hum Genet 18: 104-110, 2010.

WAGNER AK, GANDEK B, AARONSON NK, ACQUADRO C, ALONSO J, APOLONE G, BULLINGER M, BJORNER J, FUKUHARA S, KAASA S, LEPLÈGE A, SULLIVAN M, WOOD-DAUPHINEE S, WARE JE Jr: Cross-cultural comparisons of the content of SF-36 translations across 10 countries: results from the IQOLA Project. International Quality of Life Assessment. J Clin Epidemiol 51: 925-932, 1998.

WÅHLÉN K, SJÖLIN E, HOFFSTEDT J: The common rs9939609 gene variant of the fat mass and obesity associated gene (FTO) is related to fat cell lipolysis. J Lipid Res 49: 607-611, 2008.

WARDLE J, LLEWELLYN C, SANDERSON S, PLOMIN R: The FTO gene and measured food intake in children. Int J Obes (Lond) 33: 42-45, 2009.

WESTERTERP KR, GORIS AHC: Validity of the assessment of dietary intake: problems of misreporting. Curr Opin Clin Nutr Metab Care 5: 489-493, 2002.

WILLETT WC, SAMPSON L, STAMPFER MJ, ROSNER B, BAIN C, WITSCHI J, HENNEKENS CH, SPEIZER FE: Reproducibility and validity of a semiquantitative food frequency questionnaire. Am J Epidemiol 122: 51$65,1985$. 